Article

\title{
Effect of Plant Growth Promoting Bacteria on the Growth of Wheat Seedlings Subjected to Phosphate Starvation
}

\author{
Mariagrazia P. Cataldi ${ }^{1}$, Sigrid Heuer ${ }^{2}$, Tim H. Mauchline ${ }^{2}$, Mark D. Wilkinson ${ }^{2}$, \\ Emily Masters-Clark ${ }^{2}$, Nilde A. Di Benedetto ${ }^{1}$, Maria Rosaria Corbo ${ }^{1} \mathbb{D}$ and Zina Flagella ${ }^{1, *}$ \\ 1 Department of the Science of Agriculture, Food and Environment (SAFE), University of Foggia, \\ 71122 Foggia, Italy; mariagrazia.cataldi@unifg.it (M.P.C.); nilde.dibenedetto@unifg.it (N.A.D.B.); \\ mariarosaria.corbo@unifg.it (M.R.C.) \\ 2 Rothamsted Research, Harpenden, Hertfordshire AL5 2JQ, UK; sigrid.heuer@rothamsted.ac.uk (S.H.); \\ tim.mauchline@rothamsted.ac.uk (T.H.M.); mark.wilkinson@rothamsted.ac.uk (M.D.W.); \\ emily.masters-clark@rothamsted.ac.uk (E.M.-C.) \\ * Correspondence: zina.flagella@unifg.it
}

Received: 22 May 2020; Accepted: 6 July 2020; Published: 8 July 2020

\begin{abstract}
Certain phosphorous solubilizing (PSB) and phosphorous mineralizing (PMB) bacteria may improve plant growth by improving nutrient availability. The aim of this work was to evaluate the effect of inoculation with two Bacillus spp. strains, 12A and 25A, on wheat seedlings growth. To this aim, a durum and a bread wheat genotype were grown under controlled conditions in a low $\mathrm{P}$ compost medium to evaluate: (i) the effect of the bacterial isolates on plant growth and root system architecture; (ii) the expression of two key genes indicative of the P-starvation response and phosphate (Pi) uptake, TaIPS1 and TaPHT1.6-B1. The results showed that 12A Bacillus sp. significantly increased root length, surface area and biomass. Furthermore, an enhanced shoot dry weight and P content were observed. This might be explained by the capacity of strain 12A to produce indole-3-acetic acid (IAA) in addition to P mineralizing and P solubilizing capability. No effect on plant growth was observed for 25A strain. The semi-quantitative gene expression analysis showed an overall lower expression of TaIPS1 in the inoculated plants and highest expression of TaPHT1.6-B1 in 12A inoculated plants. This suggests that Pi-responsive genes might be useful molecular indicators for the effectiveness of PSB and PMB.
\end{abstract}

Keywords: PGPB; wheat; P-solubilizing bacteria; P-mineralizing bacteria; P-deficiency; IAA; root architecture; TaIPS1; TaPHT1.6-B1

\section{Introduction}

Phosphorus $(\mathrm{P})$ is an essential macronutrient for plants, being a structural component of nucleic acids, phospholipids and adenosine triphosphate (ATP), as a key element of metabolic and biochemical pathways, important particularly for biological nitrogen fixation (BNF) and photosynthesis [1]. Even if $\mathrm{P}$ is abundant in soil in both organic and inorganic forms, it represents a limiting factor for plant growth since only a small quantity is available for root uptake. It is known that about $50 \%$ of global cultivated land suffers from $P$ deficiency because of insufficient $P$ replacement into agricultural systems or because it is immobilized soon after it is applied to soil rendering Pi unavailable to plants [2]. This is due to its high reactivity with cations such as calcium and magnesium in calcareous soils or aluminium and iron in acidic soils [3]. P deficiency severely limits crop yield and regular fertilizer applications are required to obtain the high yields needed to feed the ever-increasing world population. Recent reports suggest that global consumption of $\mathrm{P}$ fertilizer is increasing with an estimated 47 million tonnes of 
$\mathrm{P}_{2} \mathrm{O}_{4}$ required by 2018 [2]. Despite increasing fertilizer use, $\mathrm{P}$ use efficiency (PUE) has been estimated to be as low as $16 \%$ across cereals [4] with severe consequences for the environment, not only because of diminishing $P$ reserves, but also because an increase in the release of $P$ from agricultural effluent leading to the eutrophication of water, enhancing the critical problem of toxic algae blooms [3].

The central importance of phosphate (Pi) in plant nutrition and agricultural sustainability has long been recognized. In the past few years, considerable efforts have been made to understand how plants adapt to low-Pi stress and the mechanisms that increase Pi uptake, transport and utilization. Plant uptake of available Pi from soil occurs through the action of high- and low-affinity Pi transporters (PHTs), which are also responsible for internal Pi distribution, as well as for storage and remobilization of Pi from the vacuole. Pi uptake is affected by root architecture and root exudation of organic acids (e.g., citric, malic and oxalic acids) and enzymes (phosphatases and phytases) into the rhizosphere solubilizing inorganic $P$ complexes and mineralizing organic $P$, respectively $[2,5]$.

In addition, in the last few decades, different regulatory pathways involved in Pi deficiency response in plants have been described. For example, a Pi-mediated signaling cascade involving the non-coding gene INDUCED BY Pi STARVATION 1 (IPS1), the small RNA miR399 and its target PHO2 are induced by P deficient soil conditions. IPS1 is amongst the most highly induced genes in response to Pi starvation in various species, including wheat [6]. IPS transcripts have been shown to inhibit the action of miRNA399-mediated silencing of $\mathrm{PHO} 2$ (a ubiquitin E2 conjugase) thereby adjusting the transcript levels of $P H O 2$, which is a key player in balancing Pi with respect to its supply and demand [7-9]. AtPHO2 has been shown to be involved in the regulation of PHT1 genes such as AtPHT1.8 and AtPHT1.9 in Arabidopsis [10,11] and OsPHT1.2 and OsPHT1.8 in rice [12]. In rice, the kinetics of two Pi transporter genes have been investigated in detail classifying Ospht2;1 as a low-affinity and OsPht6.1 as a high affinity transporter [13] and the induction of OsPht6.1 by Pi starvation was subsequently confirmed in independent studies in rice and wheat $[14,15]$. Such Pi-starvation induced genes are thus robust molecular indicators of the Pi-starvation response in plants and might be useful to assess the effect of plant growth promoting bacteria (PGPB).

The role of soil microbes present in the plant rhizosphere has gained importance in order to increase Pi plant nutrition and agricultural sustainability, as well as in relation to low Pi availability. The issue of sustainability of production is more acute in semi-arid and arid regions, such as Mediterranean arable lands. In the Mediterranean area, wheat is one of the most extensively cultivated cereals and, together with corn and rice, provides $50 \%$ of human's dietary energy requirement [16].

Phosphate-solubilizing microorganisms are a group of PGPB known to dissolve both, inorganic and organic P and to maintain soil nutrient levels [9]. Phosphate-solubilizing microorganisms are classified into P-solubilizing bacteria (PSB) and P-mineralizing bacteria (PMB) depending on the P sources utilized and the mechanisms leading to $\mathrm{P}$ availability for the plant; and $\mathrm{P}$ solubilization and mineralization activity could coexist in the same bacterial strain $[17,18]$. The inoculation of soil with microorganisms able to mobilize soil $\mathrm{P}$ through solubilization or mineralization, respectively, represents a promising strategy for the improvement of plant growth in soils with low Pi availability $[19,20]$. The main mechanism of microbial Pi solubilization is via the production of mineral-dissolving compounds, such as organic acids, siderophores, protons, hydroxyl ions and $\mathrm{CO}_{2}[5,21]$. Organic acids such as propionic and oxalic acid and their carboxyl and hydroxyl ions chelate cations and/or reduce the $\mathrm{pH}$ to release Pi [17,22]. Jiang et al. [17] identified potential PSMs from saline soil and proposed that organic acid production was the main mechanism for Pi solubilization. An alternative mechanism to organic acid production for solubilization of mineral $\mathrm{P}$ is the release of $\mathrm{H}^{+}$to the outer surface in exchange for cation uptake or with the help of $\mathrm{H}^{+}$translocating ATPase [5,21]. Organic $\mathrm{P}$, which represents about $50-70 \%$ of the total $\mathrm{P}$ in soils, is stored largely as phytate, which is not available for plant use. Phytate can be solubilized by phytases produced by $\mathrm{P}$ mineralizing bacteria (PMB). Other enzymes produced by PSB in the process of organic P mineralization are phosphatases. The major source of phosphatase activity in soil is considered to be of microbial origin, as confirmed by the presence of a significant amount of microbial phosphatase activity detected in different types of soils [21]. 
Certain PSB and PMB may improve plant growth not only by making unavailable P available for plant uptake, but also by increasing root surface area due to their ability to synthesize and export the root-growth promoting hormone auxin [23]. Indeed, it is reported that auxin level is usually higher in the rhizosphere, where a higher percentage of rhizosphere bacteria than in bulk soil is present due to the rich supply of root exudates [23]. Indole acetic acid (IAA) is the most abundant auxin produced and it has been recognized as an important factor contributing to the stimulation of root development in plants [23]. Given the chemical immobilization of $P$ in soils, root growth and architecture are key traits for optimizing Pi uptake. Only $20 \%$ of the topsoil is explored by roots during plant growth, therefore enhancing topsoil foraging is essential to improve Pi uptake [3].

There are reports of promotion of plant growth after inoculation with commercial PGPB, which solubilize inorganic Pi and mineralize organic $\mathrm{P}$ in soils. In addition, such inoculants have been shown to influence root growth and the expression of Pi transporter genes [24-26]. Some recent studies have focused on the isolation, characterization and evaluation of PSB and PMB with potential to promote plant growth under sub-optimal conditions [27-31]. In this context, the aim of the present work was to evaluate the effect of plant inoculation with two autochthonous Bacillus sp. strains on the growth of durum wheat and bread wheat seedlings. Plants were grown under controlled low-P conditions to evaluate: (i) the effect of the bacterial isolates on plant growth and root system architecture; (ii) to assess if differences in Pi-starvation induced genes (TaIPS1 and TaPHT1.6-B1) can be detected in response to the treatment.

\section{Materials and Methods}

\subsection{Preparation of Bacterial Inocula}

Two autochthonous P-solubilizing and P-mineralizing strains, 12A Bacillus sp. (GenBank accession no. MG515472.1) and 25A Bacillus sp. (GenBank accession no. MG515463.1) were used in this experiment. As reported in Di Benedetto et al. [32], 12A and 25A differed in their level of P-mineralization with strain $12 \mathrm{~A}$ characterized by a two-fold higher P-mineralizing activity than $25 \mathrm{~A}$. In addition, 12A was also capable of IAA production. Pure cultures of the selected strains, as well as an E. coli control were grown up to the $10^{8} \mathrm{cell} / \mathrm{mL}$ in nutrient broth (Oxoid, Milan, Italy). Cell cultures were harvested by centrifugation ( $353 \mathrm{~g}, 5 \mathrm{~min}$ ) and washed once with sterile Ringer's buffer $(7.2 \mathrm{~g} \mathrm{NaCl}$, $0.17 \mathrm{~g} \mathrm{CaCl}_{2}, 0.37 \mathrm{~g} \mathrm{KCl}$ per liter, $\mathrm{pH}$ 7.3-7.4). The viable count of each suspension was $10^{8} \mathrm{cell} / \mathrm{mL}$. According to Liu et al. [33], the inoculated buffer was used to inoculate compost medium as reported in the following sections. At seedling harvest soil bacterial count ranged between $1.2 \times 10^{8}$ and $1.7 \times 10^{8} \mathrm{cell} / \mathrm{mL}$ around the rhizosphere.

\subsection{Identification of $12 \mathrm{~A}$ and $25 \mathrm{~A}$}

The isolates $12 \mathrm{~A}$ and $25 \mathrm{~A}$ were morphologically and biochemically characterized through phenotypic tests, as reported in Di Benedetto et al. [32]. The main differences are summarized in Table 1. In particular, 12A and 25A differed for the level of $\mathrm{P}$ mineralization and for the production of IAA since the 12A strain was characterized by a two-fold higher P-mineralizing activity and by the IAA production capacity.

\subsection{Preparation of Seeds}

According to Robinson et al. [34], Triticum durum (cv. Simeto provided by University of Foggia, Italy) and bread wheat Triticum aestivum L. seeds (cv. Cadenza provided by Rothamsted Research, UK) were surface-sterilized by: (i) submerging in $70 \%$ ethanol for $5 \mathrm{~min}$; (ii) treating with a solution of $20 \%$ $\mathrm{NaClO}$ for 60 min under gentle shaking; (iii) rinsing four times with sterile distilled water. The seeds were germinated on moist filter paper in Petri dishes (10 seeds/dish), sealed with Parafilm at $18-22{ }^{\circ} \mathrm{C}$ in darkness. 
Table 1. Phenotypic characterization of 12A and 25A, selected Bacillus spp. For qualitative analyses, positive tests are reported with 1; negative with nd. Modified by Di Benedetto et al. [32].

\begin{tabular}{ccc}
\hline Assay & $\mathbf{1 2 A}$ & 25A \\
\hline catalase & 1 & 1 \\
oxidase & 1 & 1 \\
urease & nd & nd \\
motility & nd & nd \\
siderophores production & nd & 1 \\
ammonium production & 1 & 1 \\
phosphate-solubilization $\mathrm{Ca}_{3}\left(\mathrm{PO}_{4}\right)_{2}(\mathrm{HALO} \mathrm{mm})$ & 2 & 3 \\
phosphate-solubilization $\mathrm{AlPO}_{4}(\mathrm{HALO} \mathrm{mm})$ & 6 & 2 \\
phosphate-solubilization $\mathrm{Fe}\left(\mathrm{PO}_{4}\right)_{3}(\mathrm{HALO} \mathrm{mm})$ & 3 & 2 \\
P-mineralization $\left(\mu \mathrm{M}^{1}{ }^{1}\right.$ & $8.01 \pm 0.33$ & $3.96 \pm 0.20$ \\
IAA $\left(\mu \mathrm{g} / \mathrm{mL}^{2}{ }^{2}\right.$ & $5.82 \pm 0.13$ & 0 \\
\hline calibration curve was built with $\mathrm{KH}_{2} \mathrm{PO}_{4}(882 \mathrm{~nm}) .{ }^{2}$ A standard solution of indole-3-acetic acid (IAA) $(530 \mathrm{~nm})$
\end{tabular}

\subsection{Greenhouse Experiment}

Seven-day-old seedlings were transferred into black plastic pots $\left(11.5 \mathrm{~cm}\right.$ diameter, $\left.0.0132 \mathrm{~m}^{2}\right)$ containing one seedling per pot. The potting medium consisted of autoclaved $\left(126^{\circ} \mathrm{C}\right.$ for $\left.1 \mathrm{~h}\right)$ compost plus sand (Levington Advance_Seed and Modular Compost F2S). The compost was washed to remove soluble nutrients, as described by Masters-Clark et al. [35] and autoclaved for a second time after $48 \mathrm{~h}$ to inactivate any surviving spore-forming microorganisms. After washing, compost available $\mathrm{P}$ and total $\mathrm{P}$ content were $4.32 \mathrm{ppm}$ and $201.99 \mathrm{ppm}$, respectively. In order to ensure an adequate supply of plant-required nutrients, with the exception of $\mathrm{P}$, a nutrient solution without $\mathrm{P}$ was added one day after potting. The nutrient solution had the following composition: $5 \mathrm{mM} \mathrm{KCl}, 2 \mathrm{mM} \mathrm{NaNO}, 1 \mathrm{mM}$ $\mathrm{MgSO}_{4}, 9.2 \mu \mathrm{M} \mathrm{H}_{3} \mathrm{BO}_{3}, 3.6 \mu \mathrm{M} \mathrm{MnCl}_{2}, 16 \mathrm{nM} \mathrm{Na} 2 \mathrm{MoO}_{4}, 5 \mu \mathrm{M} \mathrm{KCl}$ and $770 \mathrm{nM} \mathrm{ZnCl}$ as reported in Grün et al. [15].

The soil with a medium $\mathrm{P}$ content consisted of autoclaved $\left(126^{\circ} \mathrm{C}\right.$ for $\left.1 \mathrm{~h}\right)$ and unwashed compost plus sand (Levington Advance_Seed and Modular Compost F2S). After $48 \mathrm{~h}$, the compost was autoclaved once again to inactivate spore-forming microorganisms. The available $\mathrm{P}$ and total $\mathrm{P}$ content of unwashed compost were $22.73 \mathrm{ppm}$ and $901.07 \mathrm{ppm}$, respectively.

Bacterial inoculation was performed one day after planting by adding $1 \mathrm{~mL}$ of bacterial inoculum to the compost medium close to seedling roots. Two different bacterial inocula were tested: strain 12A Bacillus sp. in Ringer's Buffer medium and strain 25A Bacillus sp. in Ringer's Buffer medium at $10^{8}$ cell $/ \mathrm{mL}$ to each pot. Control seedlings were inoculated with the same amount of non-PGPB bacteria (E. coli DH5 $\alpha$ strain, Invitrogen) in Ringer's Buffer medium). The experiment was completely randomized, with four replicates per treatment, and it was carried out in a greenhouse for 20 days with a $20 / 15^{\circ} \mathrm{C}$ day/night temperature and a photoperiod of $16 \mathrm{~h}$ /day with natural light. Supplementary lighting was provided when light intensity fell below $100 \mu \mathrm{mol}$ photons $\mathrm{m}^{2} / \mathrm{s}$ and was switched off when light intensity was above $300 \mu \mathrm{mol}$ photons $\mathrm{m}^{2} / \mathrm{s}$. Plants were kept well-watered using tap water.

\subsection{Plant and Root Sampling}

Plants were destructively harvested at 20 days after inoculation (DAI), growth media was removed from the plant roots by washing with tap water and gentle brushing. The shoots were cut off from the roots and oven-dried at $80^{\circ} \mathrm{C}$ for $48 \mathrm{~h}$ and weighed to determine the total aboveground biomass. To determine plant total $\mathrm{P}$, dried shoot samples were milled and subsequently digested with $\mathrm{HNO}_{3} / \mathrm{HClO}_{4}$ for ICP-OES analysis (performed by the Analytical chemistry unit, Rothamsted Research, Harpenden, UK).

Roots were stored in a $20 \%$ v/v ethanol solution at $4{ }^{\circ} \mathrm{C}$ until scanning. For this, roots were placed in a $30 \times 42 \mathrm{~cm}$ tray filled with $1 \mathrm{~cm}$ of tap water and scanned on a flat-bed scanner (Epson Expression $11000 \mathrm{XL}$, Epson, Japan) at a resolution of $600 \mathrm{dpi}$. The root surface area and total root length and other 
root parameters such a as tips and forks were determined from the root images using the image analysis software WinRHIZO (Arabidopsis version 2013e 32 Bit, Regent Instruments, Canada), differentiating the primary and the lateral roots with a distinguishing diameter of $0.32 \mathrm{~mm}$.

After scanning, roots were oven-dried at $80{ }^{\circ} \mathrm{C}$ for $48 \mathrm{~h}$ and weighed to determine the root dry weight.

\subsection{Total RNA Extraction and cDNA Synthesis}

Total RNA was isolated from the youngest fully expanded leaf, immediately snap-frozen in liquid nitrogen and stored at $-80^{\circ}$ until RNA extraction using $1 \mathrm{ml}$ TRIzol per $50 \mathrm{mg}$ of homogenized plant tissue according to the manufacturer's instruction (Invitrogen Cat. No. 15596-026). The RNA concentration and quality were determined by measuring 260/230 $\mathrm{nm}$ ratios using a NanoDrop (ND-SPECTROPHOMETER 1000, Wilmington, DE, USA).

Genomic DNA was removed by DNase treatment $\left(37^{\circ} \mathrm{C}\right)$ performed in a $10 \mu \mathrm{L}$ reaction volume containing $8 \mu \mathrm{L}$ of total RNA, $1 \mu \mathrm{L}$ of DNase Buffer, $1 \mu \mathrm{L}$ DNase. After $30 \mathrm{~min}$, the reaction was stopped by adding $1 \mu \mathrm{L}$ of Stop DNase Buffer and incubating at $65^{\circ} \mathrm{C}$ for $10 \mathrm{~min}$. The integrity of the DNase-treated RNA was confirmed by electrophoresis using $1 \%(w / v)$ agarose gels. Complementary DNA (cDNA) was synthesized from the DNase-treated RNA using SuperScript III Reverse Transcriptase (Invitrogen) in a total reaction volume of $20 \mu \mathrm{L}$ using $2 \mu \mathrm{g}$ total RNA, $4 \mu \mathrm{L} 5 \times$ buffer, $1 \mu \mathrm{L} 0.1 \mathrm{M}$ DTT and $1 \mu \mathrm{L}$ Superscript III Reverse transcriptase as per the manufacturer's instructions.

\subsection{Semi-Quantitative Reverse Transcriptase (RT)-PCR}

For the purpose of this study, two genes known to be highly inducible by Pi starvation were selected, namely IPS1 and PHT1.6-B1, and gene-specific primers for the putative wheat orthologs were designed for gene expression analysis via semi-quantitative reverse-transcription (RT)-PCRs. The constitutively expressed cyclophilin gene was used as internal positive control. Sequences of the primers used for the RT-PCR analysis and the accession numbers of the targeted wheat genes and their corresponding homeologs are listed in Table 2. Sequences were retrieved from NCBI (https://www. ncbi.nlm.nih.gov/) and Ensemble Plants https://plants.ensembl.org/Triticum_aestivum/Info/Index), respectively, and primers were designed by hand based on nucleotide sequence alignments.

Table 2. List of primers used in RT-PCR analysis.

\begin{tabular}{ccc}
\hline Name & Sequences & $\begin{array}{c}\text { Gene Names and } \\
\text { Accession Numbers }\end{array}$ \\
\hline IPS1 F1 & 5' CGCACACCATGTAGGCCACAA 3' & TaIPS1;1: EU753150_1 \\
IPS1 R3 & 5' CTTCATATCAATTTGGTATAGCTAGCTA 3' & TaIPS1;2: EU753151_1 \\
& & TaIPS1;3: EU753152_1 \\
\hline PHT1.6-B1 F1 & 5' AATTAACCTGGACAACTCGACC 3' & TraesCS5D02G472000.1 \\
PHTI.6-B1 R3 & 5' CTGGCGCAGAACAAGGACC 3' & TraesCS5B02G470100.1 \\
\hline TaCyc F & 5' CAAGCCGCTGCACTACAAGG 3' & TraesCS6A02G068900 \\
TaCyc $R$ & 5' AGGGGACGGTGCAGATGAA 3' & TraesCS6D02G066700 \\
& & TraesCS6B02G093100 \\
\hline
\end{tabular}

Four replicates for each factor interaction (Genotype $\times$ Inoculum) were included in every $(\mathrm{RT})-\mathrm{PCR}$ run containing: $1 \mu \mathrm{L}$ of cDNA solution or water (contamination control) and $24 \mu \mathrm{L}$ of Master Mix (DreamTaq Green PCR Master Mix 1.1X; ThermoFisher Scientific). Separate RT Master Mix reactions were prepared for each primer set. Reactions were performed as follows: $5 \mathrm{~min}$ at $95^{\circ} \mathrm{C}$ followed by 30 cycles of $95^{\circ} \mathrm{C}$ for $30 \mathrm{~s}, 58^{\circ} \mathrm{C}$ for $30 \mathrm{~s}, 72^{\circ} \mathrm{C}$ for $30 \mathrm{~s}$, and a final extension step at $72{ }^{\circ} \mathrm{C}$ for $10 \mathrm{~min}$. Five $\mu \mathrm{L}$ of the RT-PCR products were analyzed by electrophoresis in $1 \%(w / v)$ agarose gels stained with ethidium bromide $(1 \mu \mathrm{L} / 100 \mathrm{~mL})$ and observed under UV light (BIO-RAD Gel Doc XR system). 


\subsection{Statistical Analysis}

Statistical analysis was performed by using the statistical package Statistica, version 7 (StatSoft, Tulsa, OK, USA). All data were analyzed by two-way analysis of variance (ANOVA) using genotype and inoculum as factors. Tukey's test was used post-hoc to assess significant differences at $0.05,0.01$ and $0.001 \mathrm{P}$ level of significance.

\section{Results}

\subsection{Root Imaging and Plant Biomass}

Outputs from the two-way ANOVA for root growth and plant biomass of seedlings of the two investigated wheat genotypes treated with the bacterial inoculants showed a highly significant effect of the inoculum but no effect of genotype was observed for all examined variables. The interaction inoculum $\times$ genotype was significant only for root length.

Compared to control plants, plants treated with the strain 12A showed a highly significant increase in root parameters while the inoculation of plants with the $25 \mathrm{~A}$ strain had no effect. In particular, the total root length of the 12A-inoculated plants was $48.3 \%$ higher compared to control plants. A significant increase was also observed for lateral and primary root length $(+34.2 \%$ and $+74 \%$, respectively). Therefore, the total root area was significantly greater $(+50.7 \%)$ than that of control plants (Figure 1).

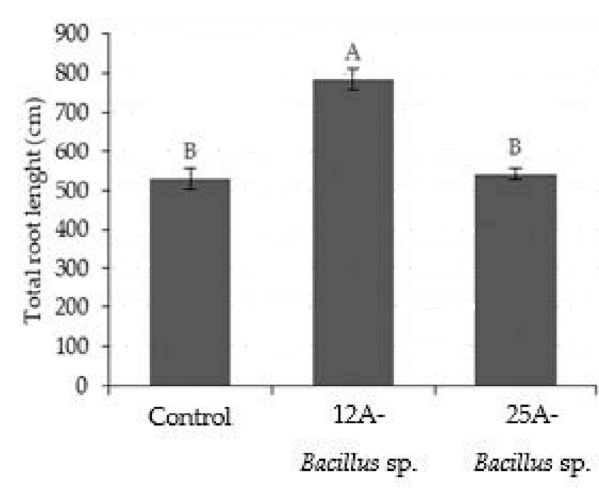

a)

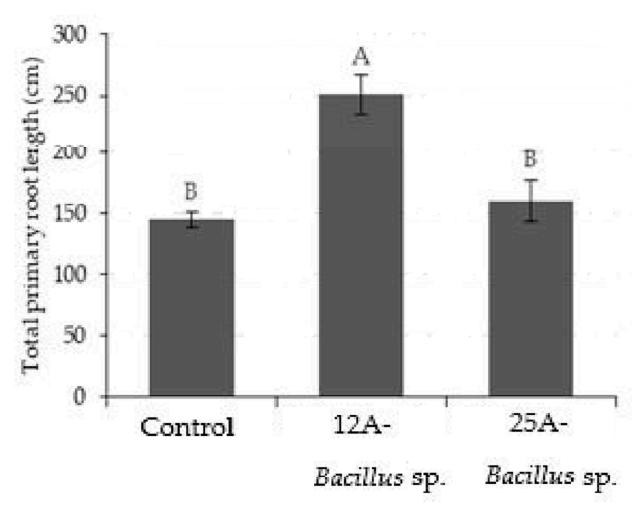

c)

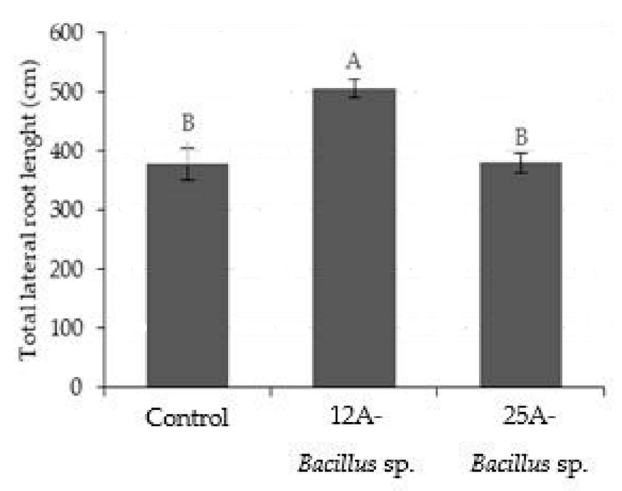

b)

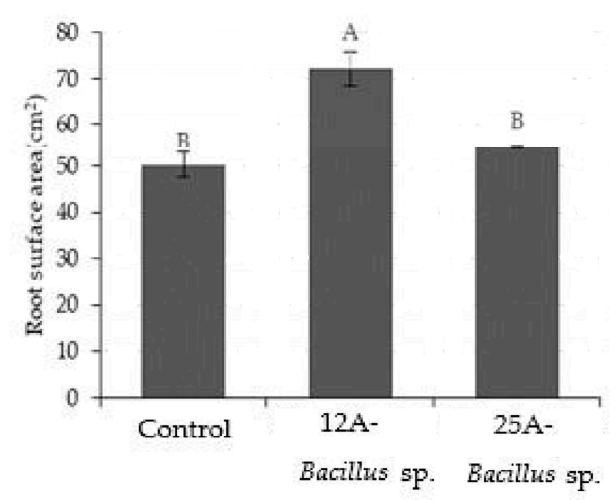

d)

Figure 1. Effect of different bacterial inoculants (control, 12A Bacillus sp., 25A Bacillus sp.) on root growth and surface area of wheat seedlings grown in low P compost medium. (a) Total root length (cm); (b) total lateral root length $(\mathrm{cm})$; (c) total primary root length $(\mathrm{cm}) ;(\mathbf{d})$ root surface area $\left(\mathrm{cm}^{2}\right)$. Data are reported as mean values $(n=8)$. Different letters indicate significant differences at $p \leq 0.001$ according to Tukey's test. 
In addition, we observed a higher root branching in 12A-inoculated plants since the number of root tips and forks ( $3230 \pm 313$ and $1086 \pm 188$, respectively) were higher than in control plants (2637 \pm 307 and $637 \pm 80$, respectively). On the contrary, 25A did not stimulate root branching and the number of tips and forks ( $2647 \pm 500$ and $667 \pm 135$, respectively) was not different from the control.

Consistent with the root scan results, average root and shoot dry weight (DW) of the plants grown in growth medium inoculated with the 12A strain were significantly $(p \leq 0.001)$ greater than that of the control plants and of plants grown in compost inoculated with $25 \mathrm{~A}(+53.4 \%$ and $+87.8 \%$, respectively) (Figure 2a,b).

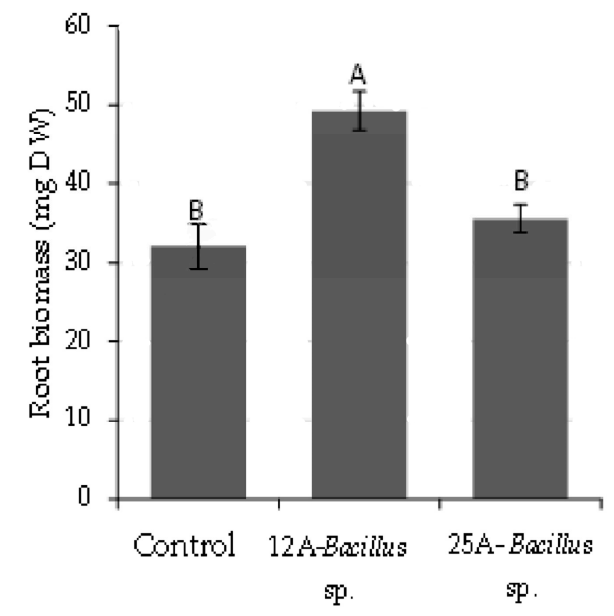

a)

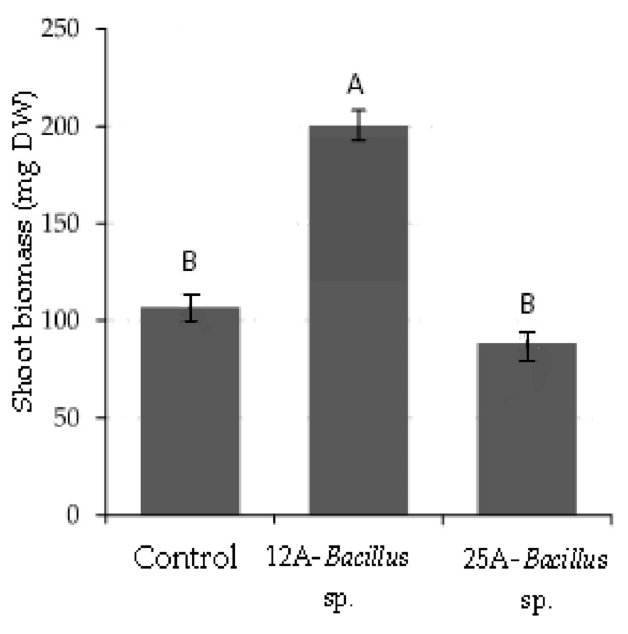

b)

Figure 2. Effect of bacterial inoculum (control, 12A Bacillus sp., 25A Bacillus sp.) on wheat seedlings biomass grown in low P compost medium. (a) Root dry weight; (b) shoot dry weight. Data are reported as mean values $(n=8)$. Different letters indicate significant differences at $p \leq 0.001$ according to Tukey's test.

Furthermore, plants treated with the 12A strain had the highest shoot $\mathrm{P}$ content $(0.86 \mathrm{mg} / \mathrm{g} \mathrm{DW})$, which was significantly $(p \leq 0.05)$ higher than that obtained with strain $25 \mathrm{~A}$ and in controls $(0.66 \mathrm{mg} / \mathrm{g}$ DW and $0.63 \mathrm{mg} / \mathrm{g}$ DW, respectively) (Figure 3).

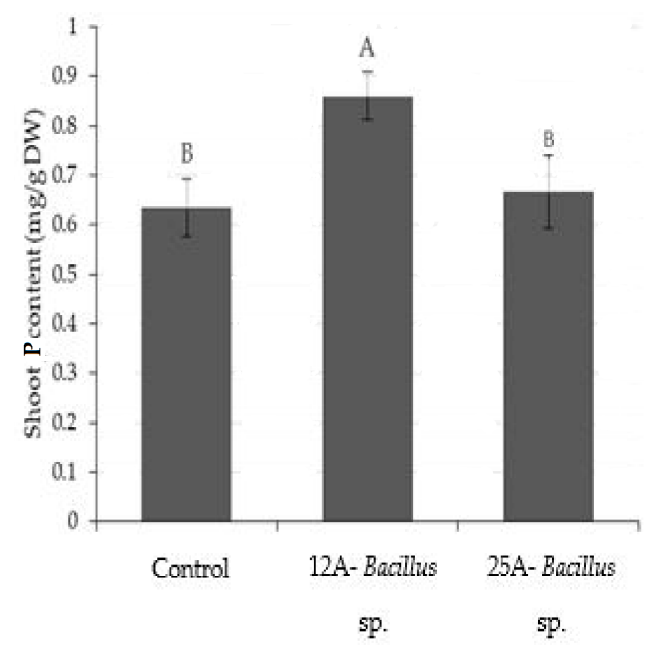

Figure 3. Effect of bacterial inoculation (control, 12A Bacillus sp., 25A Bacillus sp.) on shoot P content of wheat seedlings grown in low P compost medium. Data are reported as mean values $(n=8)$. Different letters indicate significant differences at $p \leq 0.001$ according to Tukey's test. 
Increased root growth and root surface area was evident in plants grown in pots that were inoculated with isolate 12A. This was particularly evident for Simeto, where total root length, total lateral root length and total primary root length were all significantly greater compared to other treatments. However, for Cadenza, only total primary root length was significantly different from the other treatments in response to inoculation with $12 \mathrm{~A}$ (Figure $4 \mathrm{a}-\mathrm{c}$ ).

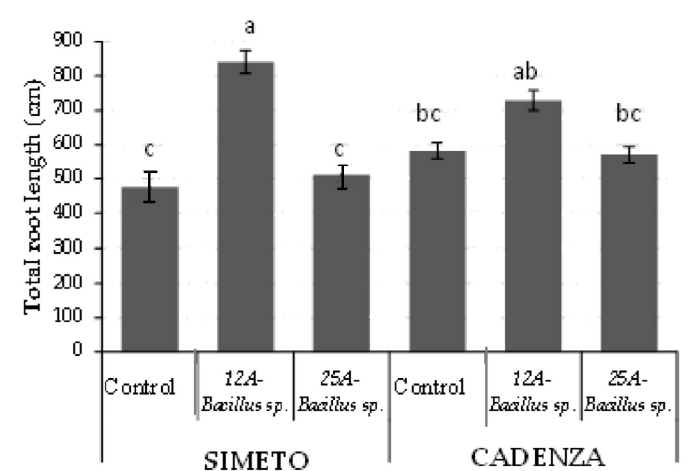

a)

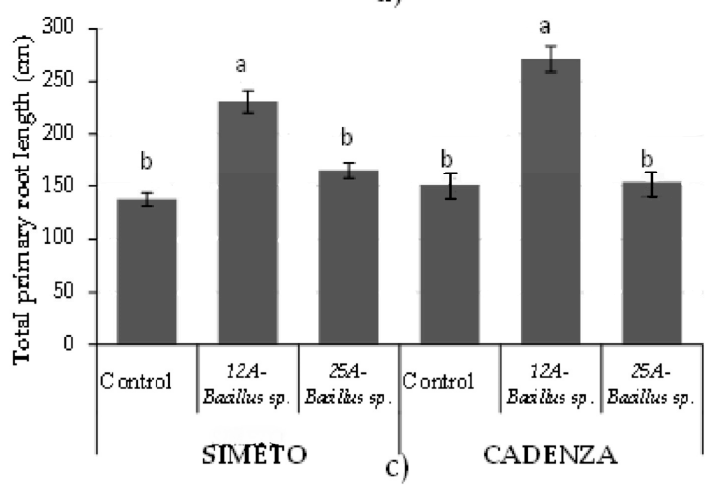

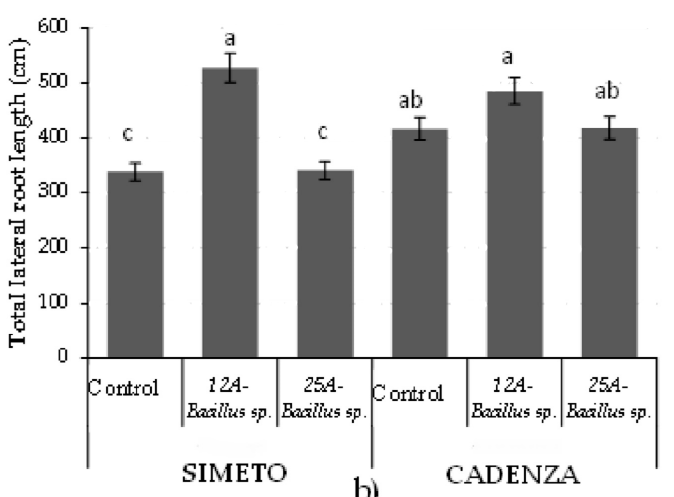

b)

Figure 4. Effect of the interaction of bacterial inoculum (control, 12A Bacillus sp., 25A Bacillus sp.) with genotype (cv. Simeto and Cadenza) on root growth of wheat seedlings grown in low P compost medium. (a) Total root length, (b) total lateral root length, (c) total primary root length. Data are reported as mean values $(n=4)$. Different letters indicate significant differences at $p \leq 0.05$ according to Tukey's test.

The effect on wheat growth of 12A and 25A strains was also evaluated on a control soil with a medium $\mathrm{P}$ content (soil available $\mathrm{P}$ and total $\mathrm{P}$ content were $22.73 \mathrm{ppm}$ and $901.07 \mathrm{ppm}$ ). No significant effect of the two strains was observed either on root and shoot weight (mean values $=25.21 \pm 1.43 \mathrm{mg}$ and $142.63 \pm 8.34 \mathrm{mg}$, respectively) or on shoot $\mathrm{P}$ content (mean value $=1.7 \pm 0.1 \mathrm{mg} / \mathrm{g}$ ). The results obtained showed in the soil with a medium $P$ content a lower root development and a higher shoot growth with respect to the $\mathrm{P}$ deficient soil.

\subsection{Expression Analysis of Representative Pi-Starvation Induced Genes}

To assess possible effects of PGPB inoculation on the Pi status of plants at the molecular level, a semi-quantitative RT-PCR gene expression analysis was conducted targeting the putative wheat orthologues of the Pi-starvation response regulator gene TaIPS1 and the high affinity Pi transporter gene TaPHT1.6-B1. These genes were selected as representative indicators for the Pi-starvation response regulatory pathway and the Pi-uptake capacity, respectively. In Figure 5, a representative analysis of leaf samples collected from four individual plants is shown. Based on this analysis, expression of the TaIPS1 gene appears to be highest and most consistent in control plants, whilst TaIPS1 expression in plants grown in pots with PGPB inoculation (12A, 25A strains) was undetectable or very low in both analyzed genotypes. In contrast, compared to control plants, a consistently higher expression of 
the TaPHT1.6-B1 gene was detected in the PGPB-inoculated plants, especially in the genotype Simeto (Figure 5a,b).

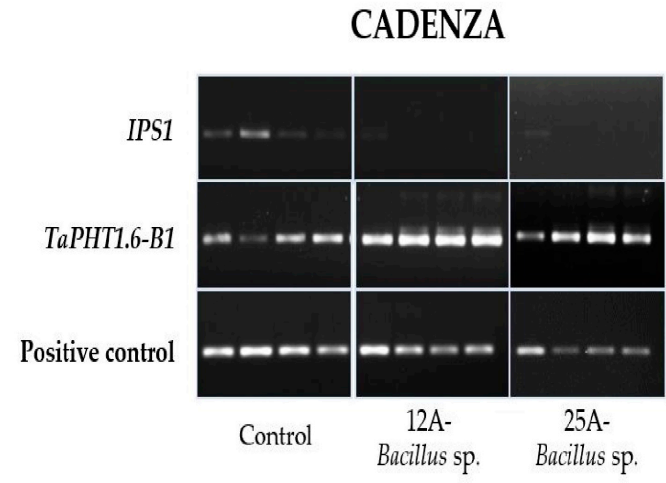

a)

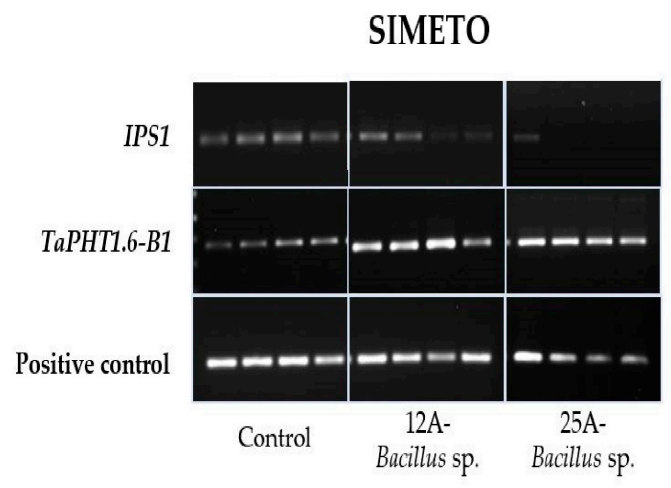

b)

Figure 5. Expression of TaIPS1, TaPHT1.6-B1 and a constitutively expressed control gene (cyclophilin positive RT-PCR control). Gene expression was analyzed by semi-quantitative RT-PCR of leaf samples collected from four individual seedlings of (a) the bread wheat cv. Cadenza and (b) the durum wheat cv. Simeto, grown in low Pi compost medium inoculated with the 12A and 25A strains.

\section{Discussion}

In this study, the capacity of autochthonous PGPB inoculum to promote the growth of wheat seedlings under low Pi condition was evaluated. Of the two tested strains, only 12A significantly increased root length, surface and biomass. Although both isolates are equally capable of solubilizing inorganic forms of phosphorous, 12A is also able to produce IAA and furthermore has a superior $\mathrm{P}$ mineralizing capacity compared to 25A [32]. The IAA production represents an important selection criterion for bacteria with regards to their application as bio-fertilizer for cultivated plants $[1,36,37]$. Bacteria that produce IAA and promote plant growth were described for different crops such as maize, wheat, soybean and rice [37-40]. It is known that high levels of bacterial IAA are associated with lateral and adventitious root formation $[38,40,41]$. In our experiment, an increase in both the primary and lateral root length was reported which might be due to IAA production.

In accordance with an extended root surface, length and biomass, inoculation with the 12A strain (IAA producer) led to greater shoot growth (dry weight). That may be a consequence of an IAA response related to increased root branching and more efficient nutrient uptake by the plant. Moreover, some authors suggest a direct effect of IAA-producing bacteria on shoot growth [42-44].

The positive effect of $12 \mathrm{~A}$ inoculation on root and shoot dry weight of plants might result from the combination of increased root length and surface area and the P mineralizing and solubilizing ability as confirmed by a high $\mathrm{P}$ content in shoot.

On the contrary, under the experimental condition applied in this study, the 25A inoculum had no effect on root development despite its ability to mineralize and solubilize P. This might be explained, at least partially, by its inability to produce IAA. In addition, it is possible that the effect of the 25A strain was not sufficient to increase plant growth and the parameters investigated in our experiment because of a lower ability to mineralize $P$ than the 12A strain. The compost medium when washed, is severely depleted in soluble forms of phosphorous [35]. However, organic forms of $P$ remain available for mineralization in the washed compost matrix. It is therefore possible that a greater mineralization capacity coupled with the ability to produce IAA explains the superior plant growth promoting effect of $12 \mathrm{~A}$ over $25 \mathrm{~A}$.

Another objective of this study was to assess the effect of PGPB inoculation on the expression of Pi-starvation induced genes as a possible molecular indicator of the severity of Pi starvation. For this purpose, two Pi-starvation induced genes, IPS1 and PHT6, were selected as representatives of 
the regulation of the IPS1-miR399-PHO2 signaling pathway and the high affinity Pi-uptake system, respectively. In the literature, it is widely reported that the IPS1-miR399-PHO2 signaling pathway directly and indirectly regulates the expression of a suite of genes, including Pi transporter genes such as PHT1.8 and PHT1.9 [10,11]. IPS1 is expressed primarily in vascular tissues of roots and shoots [45,46]. Five IPS genes are found in the Arabidopsis genome [7] and two IPS genes are present in monocotyledonous species, such as rice, maize and barley [45]. Likewise, in rice it was shown that IPS1 is highly responsive to Pi deficiency and its transcript level is a good marker for the severity of $\mathrm{P}$ deficiency responses and has been shown to be involved in P homeostasis [7,33,46-48]. IPS1 transcripts prevent the formation of the miRNA399 silencing complex with PHO2 mRNA (a ubiquitin E2 conjugase) adjusting the transcript levels of $\mathrm{PHO} 2$, a key player in balancing Pi with respect to its supply and demand since it is responsible for Pi transporter degradation [7-9]. The Arabidopsis loss-of-function mutant At4 shows high P accumulation in shoots [46] and, inversely, overexpression of AtIPS1 and At4 decreases $P$ accumulation in shoots [7], indicating that IPS genes are involved in Pi remobilization and translocation. [7,46]. IPS1 is therefore a reliable and robust molecular indictor of plant Pi responses. In wheat, three IPS1 homologs have been identified (IPS1.1, IPS1.2 and IPS1.3) [6] and those were targeted in this study.

The PHT6 gene, rather than other Pi transporter genes, was chosen for the present study because it has been classified as a high-affinity Pi transporter based on one of the few available kinetic studies available [13] and induction of PHT6 expression under Pi deficient growth conditions had been confirmed in rice [14] and also in wheat [15]. Furthermore, a study in barley suggested that PHT1.6 might be subject to the regulation of the miR399-PHO2 signaling pathway [49].

Our semi-quantitative analysis presented in Figure 5 showed that IPS1 expression was consistently higher in control plants and that expression was very low or absent in the PGPB 12A and 25A inoculated plants. This suggests that the Pi-mediated signaling cascade IPS1-miR399-UBC24/PHO2 was induced more highly in control plants inductive of a more severe Pi starvation. Contrary to the TaIPS1 expression, TaPHT6 transcript levels were consistently higher in both analyzed genotypes in the PGPB treated plants, especially in the 12A-inoculated plants, which would be inductive of a superior high-affinity Pi-uptake capacity. Although the gene expression data are only semi-quantitative and more careful analyses by quantitative RT-PCR are needed, the data are well in agreement with the shoot Pi levels, which were lowest in control plants $(0.63 \mathrm{mg} / \mathrm{g} \mathrm{DW})$ and highest in 12A-inoculated plants $(0.86 \mathrm{mg} / \mathrm{g} \mathrm{DW})$. However, shoot $\mathrm{P}$ content was only marginally higher in plants inoculated with the 25A strain $(0.66 \mathrm{mg} / \mathrm{g}$ DW) despite the absence of IPS1 expression. However, TaPHT6 was induced to a lesser extend in response to $25 \mathrm{~A}$ inoculation compared to $12 \mathrm{~A}$, and $25 \mathrm{~A}$ was also less effective in inducing root growth possibly due to its inability to produce IAA (see above).

Taken together, the finding of a low TaIPS1 and high TaPHT6 expression in PGPB-inoculated plants is in agreement with the expectation and warrants to investigate this further in a wider range of genotypes and different PGPB strains.

\section{Conclusions}

In this study, the effect of inoculation with two autochthonous strains on wheat seedlings grown under P-limiting conditions in a pot experiment was investigated. Between the two investigated strains, only 12A Bacillus sp. significantly increased root length, root surface area and root biomass. Furthermore, an enhanced shoot dry weight and shoot $\mathrm{P}$ content was found, which might be due to a combined positive effect of $12 \mathrm{~A}$ on root length and surface area, as well as mineralization and solubilization of P. On the contrary, the 25A Bacillus sp. strain did not stimulate root growth or increase plant biomass and $\mathrm{P}$ content in shoots, maybe due to its inability to produce IAA and its lower capacity to mobilize unavailable P compared with 12A strain.

The observed differences in the expression level of the two selected Pi-starvation inducible genes, i.e., low TaIPS1 and high TaPHT6 expression in inoculated plants, is in agreement with the expectations and suggests that gene expression analyses represent an easy and inexpensive way to assess beneficial 
effects of PGPB on plants. This warrants the testing of additional genes in a wider range of genotypes and PGPB strains, and the development of quantitative qRT-PCR gene expression assays.

The positive plant growth response to PGPB inoculation and the gene expression analysis, both suggest that the 12A Bacillus sp. strain is a promising candidate for biofertilizers, aiding the management of Pi-deficiency in agricultural soils. This would help to reduce application of chemical fertilizers thereby contributing to a more sustainability agriculture.

Author Contributions: Conceptualization, S.H., T.H.M., Z.F.; Methodology M.R.C., N.A.D.B., T.H.M., S.H., M.D.W.; Formal Analysis, M.P.C.; Investigation M.P.C., M.D.W, E.M.-C.; Data Curation M.P.C., S.H., Z.F.; Original Draft Preparation M.P.C., Z.F., S.H.; Writing-Review \& Editing: S.H., T.H.M., Z.F., M.R.C.; N.A.D.B., M.P.C., M.D.W. All authors have read and agreed to the published version of the manuscript.

Funding: Rothamsted Research receives strategic funding from the Biotechnological and Biological Sciences Research Council of the United Kingdom. We acknowledge support through the Designing Future Wheat (DFW) (BB/P016855/1) and "Soils to Nutrition" (BBS/E/C/000I0310) Strategic Programme. We also acknowledge the Natural Environment Research Council (NERC) under research program NE/N018125/1 LTS-M ASSIST-Achieving Sustainable Agricultural Systems (www.assist.ceh.ac.uk). Emily Masters-Clark is funded by the Teagasc Walsh Fellowship (2017150), supported by the Rothamsted-Cranfield AgRIA scheme. Scholarship of the first author was funded by University of Foggia within the PhD Course on "Management of Innovation in the Agricultural and Food Systems in the Mediterranean Region".

Conflicts of Interest: The authors declare no conflict of interest.

\section{References}

1. de Souza, R.; Ambrosini, A.; Passaglia, L.M. Plant growth-promoting bacteria as inoculants in agricultural soils. Genet. Mol. Biol. 2015, 38, 401-419. [CrossRef] [PubMed]

2. Heuer, S.; Gaxiola, R.; Schilling, R.; Herrera-Estrella, L.; López-Arredondo, D.; Wissuwa, M.; Delhaize, E.; Rouached, H. Improving phosphorus use efficiency: A complex trait with emerging opportunities. Plant J. 2017, 90, 868-885. [CrossRef] [PubMed]

3. López-Arredondo, D.L.; Leyva-Gonzalez, M.A.; Gonzalez-Morales, S.A.; Lopez-Bucio, J.; Herrera-Estrella, L. Phosphate nutrition: Improving low-phosphate tolerance in crops. Annu. Rev. Plant Biol. 2014, 65, 95-123. [CrossRef]

4. Dhillon, J.; Torres, G.; Driver, E.; Figueiredo, B.; Raun, W.R. World phosphorus use efficiency in cereal crops. Agron. J. 2017, 109, 1-8. [CrossRef]

5. Sharma, S.B.; Sayyed, R.Z.; Trivedi, M.H.; Gobi, T.A. Phosphate solubilizing microbes: Sustainable approach for managing phosphorus deficiency in agricultural soils. Springerplus 2013, 2, 587. [CrossRef]

6. Oono, Y.; Kobayashi, F.; Kawahara, Y.; Yazawa, T.; Handa, H.; Itoh, T.; Matsumoto, T. Characterisation of the wheat (triticum aestivum L.) transcriptome by de novo assembly for the discovery of phosphate starvation-responsive genes: Gene expression in Pi-stressed wheat. BMC Genom. 2013, 14, 77. [CrossRef]

7. Franco-Zorrilla, J.M.; Valli, A.; Todesco, M.; Mateos, I.; Puga, M.I.; Rubio-Somoza, I.; Leyva, I.; Weigel, A.; Garcia, D.; Paz-Ares, J. Target mimicry provides a new mechanism for regulation of microRNA activity. Nat. Genet. 2007, 39, 1033-1037. [CrossRef] [PubMed]

8. Briat, J.F.; Rouached, H.; Tissot, N.; Gaymard, F.; Dubos, C. Integration of P, S, Fe, and Zn nutrition signals in Arabidopsis thaliana: Potential involvement of phosphate starvation response 1 (PHR1). Front. Plant Sci. 2015, 6, 290. [CrossRef] [PubMed]

9. Kumar, S.; Verma, S.; Trivedi, P.K. Involvement of small RNAs in phosphorus and sulfur sensing, signaling and stress: Current update. Front. Plant Sci. 2017, 8, 285. [CrossRef]

10. Aung, K.; Lin, S.I.; Wu, C.C.; Huang, Y.T.; Su, C.L.; Chiou, T.J. pho2, a phosphate over accumulator, is caused by a nonsense mutation in a microRNA399 target gene. Plant Physiol. 2006, 141, 1000-1011. [CrossRef]

11. Bari, R.; Datt Pant, B.; Stitt, M.; Scheible, W.R. PHO2, microRNA399, and PHR1 define a phosphate-signaling pathway in plants. Plant Physiol. 2006, 141, 988-999. [CrossRef] [PubMed]

12. Wang, C.; Ying, S.; Huang, H.; Li, K.; Wu, P.; Shou, H.X. Involvement of OsSPX1 in phosphate homeostasis in rice. Plant J. 2009, 57, 895-904. [CrossRef] [PubMed]

13. Ai, P.; Sun, S.; Zhao, J.; Fan, X.; Xin, W.; Guo, Q.; Yu, L.; Shen, Q.; Wu, P.; Miller, A.J.; et al. Two rice phosphate transporters, OsPht1;2 and OsPht1;6, have different functions and kinetic properties in uptake and translocation. Plant J. 2009, 57, 798-809. [CrossRef] [PubMed] 
14. Jeong, K.; Mattes, N.; Catausan, S.; Chin, J.H.; Paszkowski, U.; Heuer, S. Genetic diversity for mycorrhizal symbiosis and phosphate transporters in rice. JIPB 2015, 57, 969-979. [CrossRef] [PubMed]

15. Grün, A.; Buchner, P.; Broadley, M.R.; Hawkesford, M.J. Identification and expression profiling of Pht1 phosphate transporters in wheat in controlled environments and in the field. Plant Biol. 2017, 20, 374-389. [CrossRef]

16. FAO. Available online: http://www.fao.org/news/story/en/item/273303/icode (accessed on 19 December 2014).

17. Jiang, H.; Qi, P.; Wang, T.; Chen, M.; Chen, N.; Pan, L.; Chi, X. Isolation and characterization of halotolerant phosphate-solubilizing microorganisms from saline soils. 3Biotech 2018, 8, 461. [CrossRef]

18. Tao, G.C.; Tian, S.J.; Cai, M.Y.; Xie, G.H. Phosphate-solubilizing and -mineralizing abilities of bacteria isolated from soils. Pedosphere 2008, 18, 515-523. [CrossRef]

19. Singh, S.; Kapoor, K.K. Inoculation with phosphate-solubilizing microorganisms and a vesicular-arbuscular mycorrhizal fungus improves dry matter yield and nutrient uptake by wheat grown in a sandy soil. Biol. Fertil. Soils 1999, 28, 139-144. [CrossRef]

20. Krey, T.; Vassilev, N.; Baum, C.; Eichler-Löbermann, B. Effects of long-term phosphorus application and plant-growth promoting rhizobacteria on maize phosphorus nutrition under field conditions. Eur. J. Soil Biol. 2013, 55, 124-130. [CrossRef]

21. Rodríguez, H.; Fraga, R. Phosphate solubilizing bacteria and their role in plant growth promotion. Biotechnol. Adv. 1999, 17, 319-339. [CrossRef]

22. Alori, E.T.; Glick, B.R.; Babalola, O.O. Microbial phosphorus solubilization and its potential for use in sustainable agriculture. Front. Microbiol. 2017, 8, 971. [CrossRef] [PubMed]

23. Spaepen, S.; Vanderleyden, J.; Remans, R. Indole-3-acetic acid in microbial and microorganism-plant signalling. FEMS Microbiol. Rev. 2007, 4, 425-448. [CrossRef] [PubMed]

24. Kumar, S.; Bauddh, K.; Barman, S.C.; Singh, R.P. Amendments of microbial biofertilizers and organic substances reduces requirement of urea and DAP with enhanced nutrient availability and productivity of wheat (Triticum aestivum L.). Ecol. Eng. 2014, 71, 432-437. [CrossRef]

25. Saia, S.; Rappa, V.; Ruisi, P.; Abenavoli, M.R.; Sunseri, F.; Giambalvo, D.; Frenda, A.S.; Martinelli, F. Soil inoculation with symbiotic microorganisms promotes plant growth and nutrient transporter genes expression in durum wheat. Front. Plant Sci. 2015, 6, 815. [CrossRef] [PubMed]

26. Ogut, M.; Er, F. Mineral composition of field grown winter wheat inoculated with phosphorus solubilizing bacteria at different plant growth stages. J. Plant Nutr. 2016, 39, 479-490. [CrossRef]

27. Gupta, M.; Kiran, S.; Gulati, A.; Singh, B.; Tewari, R. Isolation and identification of phosphate solubilizing bacteria able to enhance the growth and aloin-A biosynthesis of Aloe barbadensis Miller. Microbiol. Res. 2012, 167, 358-363. [CrossRef]

28. Sadiq, H.M.; Jahangir, G.Z.; Nasir, I.A.; Iqtidar, M.; Iqbal, M. Isolation and characterization of phosphate-solubilizing bacteria from rhizosphere soil. Biotechnol. Biotechnol. Equip. 2013, 27, 4248-4255. [CrossRef]

29. Sarker, A.; Islam, T. Phosphate solubilizing bacteria promote growth and enhance nutrient uptake by wheat. Plant Sci. Today 2014, 1, 86-93. [CrossRef]

30. Zhao, K.; Penttinen, P.; Zhang, X.; Ao, X.; Liu, M.; Yu, X.; Chen, Q. Maize rhizosphere in Sichuan, China, hosts plant growth promoting Burkholderia cepacia with phosphate solubilizing and antifungal abilities. Microbiol. Res. 2014, 169, 76-82. [CrossRef]

31. Manzoor, M.; Abbasi, M.K.; Tariq, S. Isolation of phosphate solubilizing bacteria from maize rhizosphere and their potential for rock phosphate solubilization-mineralization and plant growth promotion. Geomicrobiol. J. 2017, 34, 81-95. [CrossRef]

32. Di Benedetto, N.A.; Campaniello, D.; Bevilacqua, A.; Cataldi, M.P.; Sinigaglia, M.; Flagella, Z.; Corbo, M.A. A study on a multi-step characterization and selection of Plant Growth Promoting Bacteria from durum wheat rhizosphere to improve nutrient use efficiency. Microorganisms 2019, 7, 541. [CrossRef] [PubMed]

33. Liu, F.; Wang, Z.; Ren, H.; Shen, C.; Li, Y.; Ling, H.Q.; Wu, C.; Lian, X.; Wu, P. OsSPX1 suppresses the function of OsPHR2 in the regulation of expression of OsPT2 and phosphate homeostasis in shoots of rice. Plant J. 2010, 62, 508-517. [CrossRef]

34. Robinson, R.J.; Fraaije, B.A.; Clark, I.M.; Jackson, R.W.; Hirsch, P.R.; Mauchline, T.H. Wheat seed embryo excision enables the creation of axenic seedlings and Koch's postulates testing of putative bacterial endophytes. Sci. Rep. 2016, 6, 25581. [CrossRef] [PubMed] 
35. Masters-Clark, E.; Shone, E.; Paradelo, M.; Hirsch, P.R.; Clark, I.M.; Otten, W.; Brennan, F.; Mauchline, T.H. Development of a defined compost system for the study of plant-microbe interactions. Sci. Rep. 2020, 10, 7521. [CrossRef] [PubMed]

36. Glick, B.R. Plant Growth-Promoting Bacteria: Mechanisms and applications. Scientifica 2012, $2012,963401$. [CrossRef] [PubMed]

37. Di Benedetto, N.A.; Corbo, M.R.; Campaniello, D.; Cataldi, M.P.; Bevilacqua, A.; Sinigaglia, M.; Flagella, Z. The role of Plant Growth Promoting Bacteria in improving nitrogen use efficiency for sustainable crop production: A focus on wheat. AIMS Microbiol. 2017, 3, 413-434. [CrossRef]

38. Spaepen, S.; Dobbelaere, S.; Croonenborghs, A.; Vanderleyden, J. Effects of Azospirillum brasilense indole-3-acetic acid production on inoculated wheat plants. Plant Soil 2008, 312, 15-23. [CrossRef]

39. Ali, B.; Sabri, A.N.; Ljung, K.; Hasnain, S. Auxin production by plant associated bacteria: Impact on endogenous IAA content and growth of Triticum aestivum L. Lett. Appl. Microbiol. 2009, 48, 542-547. [CrossRef]

40. Majeed, A.; Abbasi, M.K.; Hameed, S.; Imran, A.; Rahim, N. Isolation and characterization of Plant Growth-Promoting Rhizobacteria from wheat rhizosphere and their effect on plant growth promotion. Front. Microbiol. 2015, 6, 198. [CrossRef]

41. Patten, L.; Glick, B.R. Role of Pseudomonas putida indoleacetic acid in development of the host plant root system. Appl. Environ. Microbiol. 2002, 68, 3795-3801. [CrossRef]

42. Ribeiro, V.P.; Marriel, I.E.; Sousa, S.M.; Lana, U.G.P.; Mattos, B.B.; Oliveira, C.A.; Gomes, E.A. Endophytic Bacillus strains enhance pearl millet growth and nutrient uptake under low-P. Microbiol. Braz. J. Microbiol. 2018, 1, 40-46. [CrossRef] [PubMed]

43. Dodd, I.C.; Zinovkina, N.Y.; Safronova, V.I.; Belimov, A.A. Rhizobacterial mediation of plant hormone status. Ann. Appl. Biol. 2010, 157, 361-379. [CrossRef]

44. Pérez-de-Luque, A.; Tille, S.; Johnson, I.; Pascual-Pardo, D.; Jurriaan Ton, J.; Cameron, D.D. The interactive effects of arbuscular mycorrhiza and plant growth-promoting rhizobacteria synergistically enhance host plant defences against pathogen. Sci. Rep. 2017, 7, 16409. [CrossRef]

45. Hou, X.L.; Wu, P.; Jiao, F.C.; Jia, Q.J.; Chen, H.M.; Yu, J.; Song, X.W.; Yi, K.K. Regulation of the expression of OsIPS1 and OsIPS2 in rice via systemic and local Pi signaling and hormones. Plant Cell Environ. 2005, 28, 353-364. [CrossRef]

46. Shin, H.; Shin, H.S.; Chen, R.; Harrison, M.J. Loss of At4 function impacts phosphate distribution between the roots and the shoots during phosphate starvation. Plant J. 2006, 45, 712-726. [CrossRef] [PubMed]

47. Hammond, J.P.; White, P.J. Sucrose transport in the phloem: Integrating root responses to phosphorus starvation. J. Exp. Bot. 2008, 59, 93-109. [CrossRef] [PubMed]

48. Doerner, P. Phosphate starvation signaling: A threesome controls systemic Pi homeostasis. Curr. Opin. Plant Biol. 2008, 11, 536-540. [CrossRef]

49. Huang, C.Y.; Shirley, N.; Genc, Y.; Shi, B.; Langridge, P. Phosphate Utilization Efficiency Correlates with Expression of Low-Affinity Phosphate Transporters and Noncoding RNA, IPS1, in Barley. Plant Physiol. 2011, 156, 1217-1229. [CrossRef]

(C) 2020 by the authors. Licensee MDPI, Basel, Switzerland. This article is an open access article distributed under the terms and conditions of the Creative Commons Attribution (CC BY) license (http://creativecommons.org/licenses/by/4.0/). 